УДК 351/354(4)

DOI https://doi.org/10.32851/tnv-pub.2021.3.6

\title{
ЕВОЛЮЦІЯ УПРАВЛІННЯ ЗНАННЯМИ У ПУБЛІЧНОМУ СЕКТОРІ
}

\author{
Козак О.М. - аспірант кафедри регіональної політики \\ Навчально-наукового інституту публічного управління та державної служби \\ Київського національного університету імені Тараса Шевченка \\ ORCID: 0000-0002-3994-2463
}

У статті досліджено процес формування та становлення управління знаннями. Описано еволюиію наукових підходів до застосування управління знаннями у публічному секторі й узагальнено основні визначення иього поняття. Представлено інструменти з управління знаннями, які дозволили забезпечити трансформацію неформалізованих знань, досвіду та навичок публічних службовців у формалізовані знання публічних органів влади.

Встановлено, шо поштовхом до активного застосування теорії управління знаннями у системі публічних відносин стала поява у 80-х рр. минулого сторіччя управлінської кониепиї Нового публічного менеджменту. Доведено, шчо іншим стимулюючим фактором активного застосування управління знань у системі публічного управління став розвиток сучасного суспільного стану як постіндустріального інформаційного суспільства, у якому провідну роль відіграють науково-технічні досягнення.

Стосовно значення управління знаннями в електронному уряді зазначено, щсо управління знаннями забезпечують загальну стратегію управління змістом електронного врядування, надаючи інструменти та методи організачії знань, відстежуючи актуальність змісту знань і надаючи громадянам усю необхідну інформачію. Установлено переваги у застосуванні управління знаннями в електронному урядуванні, які сприяють підвищенню компетентності урядів, підвищенню якості публічних послуг $i$ здоровому розвитку електронного врядування.

Визначено, щу управління знаннями у публічних органах влади є надзвичайно складним проиесом багаторазової взаємодї формалізованих і неформальних знань, який супроводжується формуванням нової організачійної культури, створенням команди однодумиів, котрі спільно працюють над вирішенням конкретних проблем.

Обгрунтовано те, щьо у системі публічної влади знаннями необхідно керувати ефективно у часі та з огляду на витрати, щоб поєднувати громадян із громадянами та громадян із владою $i$, навпаки, для прийняття державних політик і рішень за участю громадськості.

Ключові слова: публічний сектор, управління знаннями, публічне управління, електронний уряд, новий публічний менеджмент.

\section{Kozak O.M. Evolution of knowledge management in the public sector}

The article examines the process of formation and establishment of knowledge management. The evolution of scientific approaches to the application of knowledge management in the public sector is described and the main definitions of this concept are summarized. The tools of knowledge management are presented, which made it possible to ensure the transformation of non-formalized knowledge, experience and skills of public officials into formalized knowledge of public authorities.

It has been established that the impetus for the active application of the theory of knowledge management in the system of public relations was the emergence in the $80 \mathrm{~s}$ of the last century of the management concept of the New Public Management. It is proved that another stimulating factor for the active use of knowledge management in the public administration system is the development of the modern social position as a post-industrial information society, in which scientific and technological achievements play a leading role.

Considering the importance of knowledge management in e-government, it is pointed out that knowledge management provides an overall strategy for managing e-government content by providing tools and methods for organizing knowledge. The advantages of applying knowledge management in e-government have been identified, which contribute to the improvement of the competence of governments, improve the quality of public services and contribute to the healthy development of e-government. 
It has been established that knowledge management in public authorities is an extremely complex process of repeated interaction of formalized and informal knowledge, which is accompanied by the formation of a new organizational culture, the creation of a team of like-minded people working together to solve specific problems.

It is substantiated that in the system of public power knowledge must be managed efficiently in time and taking into account costs in order to ensure the interaction of citizens with citizens and citizens with the government and, conversely, for the adoption of state policies and decisions with the participation of the public.

Key words: public sector, knowledge management, public administration, e-government, new public management.

Постановка проблеми. Категорія управлінської діяльності, яка охоплює професійну діяльність публічних службовців в Україні, привертає значну увагу дослідників. Це пояснюється сучасними викликами до сфери публічного управління, що зорієнтовані на досягнення європейських управлінських стандартів. Сьогодні активно розвивається поступова переорієнтація з розгляду окремо державної служби та служби в органах місцевого самоврядування на їх системне бачення у контексті розвитку публічної служби.

Децентралізаційні зміни, які відбулися в Україні останніми роками, зумовили також зміну парадигми у діяльності усього державного апарату. Сьогодні діяльність більшості посадовців пов'язана з розробкою та впровадженням інноваційних продуктів, що потребує від них оволодіння новими знаннями, навичками, а також методичними підходами, які можуть бути використані для вирішення організаційних питань щодо створення інновацій.

Створення інновацій у такій складній управлінській сфері, як публічне управління передбачає від публічних службовців здійснення професійно-кваліфікаційної переорієнтації кадрів відповідно до інноваційних трансформацій і застосування технологій із управління знаннями як одного із ключових чинників розвитку, реалізації й удосконалення працівників інститутів публічного управління.

Зазначене змушує більш уважно придивитися до такої категорії, як «управління знаннями», а також присвятити увагу вивченню досвіду формування, становлення та розвитку управління знаннями у публічному секторі.

Аналіз останніх досліджень і публікацій. Поштовхом до розвитку теорії управління знаннями на рівні публічного сектору стало активне використання управління знаннями в економічній сфері суспільних відносин. Дослідники кінця другої половини XX та початку XXI ст. грунтовно описали феномен знань, їх сутність, роль і механізми їх управління. Доробками у цьому напрямі відзначилися такі вчені, як Р. Балі, У. Буковіч, Ш. Депре та Д. Шовель, Л. Едвінссон, М. МакЕлрой, I. Нонака та Х. Такеучі, К. Поппер, М. Саттон, К. Свейби, Х. Скарбороу, Д. Тан, А. Тоффлер та ін. Вітчизняні вчені також доклалися до цього напрямку досліджень. Серед них можна виділити роботи О.Л. Гапоненко, А. Воронкової, Б.З. Мільнера, Т.М. Орлової, Л.І. Федулова, Н. Алюшиної, М. Марінічева, В.В. Томаха, Ю.В. Сивопляса, Т.В. Маматової.

Незважаючи на велику кількість робіт, присвячених питанням управління знаннями, обрану для дослідження тему можна вважати недостатньо розробленою. Це пояснюється актуальністю та практичною значимістю застосування інструментів управління знаннями у публічному секторі, які здатні підвищити ефективність робот публічних органів влади завдяки оптимізації, підвищенню ефективності розподілу, поширення та використання знань.

Формування цілей статті. Метою статті є дослідження формування, становлення та розвитку управління знаннями у публічному секторі. 
Виклад основного матеріалу дослідження. Поштовхом до активного застосування теорії управління знаннями у системі публічних відносин стала поява у 80-х рр. минулого сторіччя нової філософії публічного управління, спрямованої на модернізацію державного сектору, яка отримала назву парадигми Нового публічного менеджменту (New Public Management), котра має такі основні елементи, як конкуренція, стандарти ефективності, моніторинг, вимірювання, гнучкість, акцент на результатах, орієнтація на клієнта та соціальний контроль, проте подальше використання НПМ призвело до того, що з'явилися критичні зауваження на його адресу, які полягали у тому, що ця модель ігнорує різницю між приватним і державним секторами [6], громадськими інтересами, ринком і суверенітетом [23]. Ця модель публічного управління у нерозвинених демократіях призвела до концентрації влади та знань всередині урядів, до виключення інших зацікавлених сторін із процесу розробки політики. Критики стверджують, що активне застосування НПМ призвело до падіння етичних стандартів у громадському житті зі збільшенням випадків корупції та фаворитизму [16].

Іншим стимулюючим фактором активного застосування управління знань у системі публічного управління став розвиток сучасного суспільного стану як постіндустріального інформаційного суспільства, у якому провідну роль відіграють науково-технічні досягнення, а тому особливу цінність придбавають інновації. На думку К. Нордстрема та Й. Ріддерстрале, нині «тотальна інноваційність це образ мислення, який стосується кожного, усього, усюди та не має меж» [4]. У такому суспільстві дослідницькі результати та розробки - знання - стають основним ресурсом розвитку організацій. На відміну від інших ресурсів, знання як ресурс мають унікальні якості та властивості. Наприклад, у процесі споживання знання не виснажуються, а збільшуються; обмін ними збагачує обидві сторони; їх використання змінює не лише процес, але й усю сферу соціально-економічних відносин.

Перехід від Web 1.0 (винахід Інтернету) до Web 2.0 (епоха мереж) прискорив перехід від управлінського підходу у вигляді НПМ до мереж, заснованих на участі, що визначилося заміною технічної ефективності та ринкових цілей на практику спільного виробництва політики. Незважаючи на те, що співпраця через мережі підвищила ефективність у вигляді зниження транзакційних витрат і прискорила процес вироблення інновацій, вона також сприяла появі великої кількості інформації, яка висунула на передній план нові форми невизначеності, складності та втрату уваги у виробленні управлінських рішень [27].

Зміни в управлінських моделях (бюрократична, НПМ, мережева) почали розвиватися, хоча і повільніше, за змінами у суспільстві (х, у та z покоління [18]), а також за змінами у технологіях (Web 1.0, Web 2.0, Web 3.0, Web 4.0, [2]). Ocoбливістю цих змін стало те, що, поки покоління «у» (соціальні мережі: покоління розумних) прагнуло отримувати та виробляти експоненційні обсяги інформації, не піклуючись про іiї значення, контекст чи достовірність, перед поколінням «Z» стоїть завдання навчитися вибирати, аналізувати, інтегрувати, інтерпретувати інформацію перед іiі використанням (генерація інтелекту). Перехід від Web 1.0 до Web 2.0 характеризувався еволюцією використання Інтернету від пасивного споживання контенту до більш активного процесу обміну інформацією. Характерною особливістю переходу до Web 3.0 став аналіз, синтез, інтерпретація та використання колективних знань (поєднання інтелекту та семантики).

На думку Д. Тапскотта, технологічна, соціальна, демографічна й організаційна революції виявили нові проблеми, котрі вимагають нових знань від різних 
зацікавлених сторін, що породжує нові форми складності та невизначеності, сигналізуючи про роль управління знаннями у створенні, зборі, організації, передачі й обміні інформацією та стратегічними знаннями, які використовуються для прийняття рішень [26].

Починаючи з 90-х pp. XX ст. знання починають визнаватися найбільш важливим фактором виробництва в умовах «нової економіки» [12], проте відсутність інструментів і методології створювали невизначеність для використання знань в управлінських процесах, а відсутність чітких і всеохоплюючих концепцій не розвивали сферу управління знаннями [9]. На думку М. Саттона, науковці були в активному пошуку щодо визначення феномену «управління знаннями», щоби зрозуміти, що це за категорія і з чого вона складається [25]. Більшість сконцентрувалися на виявленні управлінських технологій, додатків, практик, моделей і систем взаємодії, специфічних для управління знаннями [10].

Часом, коли до управління знань привернули свою увагу науковці, можна вважати 1995 рік. Це стало можливим завдяки публікації фундаментальної книги I. Нонаки та X. Такеучі «Компанія, що створює знання» [21], а також проведенню у 1996 р. наукової конференції «Знання для стратегічних переваг», організованої А. Андерсеном та Американськимцентромпродуктивності та продуктів(APQC) [5].

Сьогодні існує велика кількість поглядів і концепції щодо визначення та розуміння управління знаннями. Це і сукупність процесів, які керують створенням, поширенням і використанням знань для досягнення цілей організації [13]. Чітко окреслене та систематичне управління важливими для організації знаннями і пов'язаними з ними процесами управління, збирання, організації, дифузії, застосування й експлуатації з метою досягнення цілей організації [24]. Широкий набір організаційних практик, пов'язаних зі створенням, охопленням, поширенням ноу-хау та сприянням обміну знаннями в організації та із зовнішнім світом [22]. Процес, який дає можливість отримувати, інтегрувати, трансформувати, застосовувати та розповсюджувати знання всіх типів і видів із метою розв'язання актуальних проблем, задоволення потреб і створення нових можливостей [3]. Будь-яка діяльність, мета якої - складати схему, збирати, систематизувати, розділяти, розвивати та використовувати ефективно збережені, задокументовані знання, компетентність і досвід організації [1]. Це забезпечення передачі знань у потрібне місце й у потрібний час для ефективного використання [11].

Виходячи із наведених формулювань, управління знаннями визначається як термін або підхід для створення, зберігання / пошуку, обміну та застосування знань. Усі ці функції взаємозв'язані та взаємозалежні під егідою управління знаннями. Ціль управління знаннями - максимально ефективне використання наявних ресурсів і можливостей. Управління знаннями надає необхідні інструменти, методи, процеси та платформи для забезпечення своєчасної доступності та доступності знань із метою підвищення ефективності діяльності організацій.

Повертаючись до розвитку управління знань у публічному секторі, можна зазначити, що, як і у випадку з НПМ, цей сектор намагається копіювати механізми застосування управління знаннями на своєму рівні. На думку С. Конга та К. Пандія, це виходить із проактивного ставлення до практик управління знаннями, які $\epsilon$ більш поширеними у приватному секторі та їх адаптації до умов публічного управління [8].

На думку британської дослідниці Кароліни Браун, сучасні приклади управління знаннями у публічному секторі часто мають вузьку спрямованість і не надають великих даних про стратегії та досвід тих, хто бере участь у процесі їх застосування 
[7]. Дослідження, що стосуються управління знаннями, здебільшого фокусуються на ролі технологій чи послуг через використання електронного уряду [17].

Це призвело до того, що більшість держав інвестували у запровадження електронного уряду для покращення внутрішньої та зовнішньої комунікації, а також якості та швидкості обслуговування. Британський дослідник у сфері державного управління Р. Хікс зазначає, що електронний уряд охоплює три основні сфери:

вдосконалення державних процесів/електронного адміністрування за рахунок скорочення часу та витрат на процеси, управління продуктивністю процесів, встановлення стратегічних зв'язків в уряді та розширення прав і можливостей;

підключення громадян (електронні громадяни й електронні послуги) шляхом надання громадянам детальної інформації про діяльність публічного сектору, збільшення вкладу громадян у рішення та дії публічних органів влади та покращення публічних послуг;

побудова зовнішньої взаємодії шляхом створення електронного суспільства, яке передбачає поліпшення відносин між державними агенціями та іншими публічними та приватними компаніями, взаємодію між урядом і бізнесом. Електронний уряд вимагає, щоб інтернет-технології забезпечували полегшений доступ до урядової інформації та послуг, а також участь громадян і підприємств через портали електронного уряду як колективне бачення всієї діяльності уряду [14]. Таким чином, електронний уряд може використовуватися для позначення публічного врядування, котре використовує інформаційні технології для надання доступу до публічної інформації та надання публічних послуг громадянам, а також усім іншим партнерам і заінтересованим сторонам, включаючи приватний сектор.

Розглядаючи значення управління знаннями в електронному уряді, можна зазначити, що управління знаннями забезпечують загальну стратегію управління змістом електронного врядування, надаючи інструменти та методи організації знань, відстежуючи актуальність змісту знань і надаючи громадянам усю необхідну інформацію. На думку 3. Чжоу та Ф. Гао, існує три переваги у застосуванні управління знаннями в електронному урядуванні, які сприяють підвищенню компетентності урядів, підвищенню якості публічних послуг і здоровому розвитку електронного врядування. Знаннями необхідно керувати ефективно у часі та 3 огляду на витрати, щоб поєднувати громадян із громадянами та громадян із владою i, навпаки, для прийняття державних політик і рішень за участю громадськості. Це забезпечує прозорість влади та розширення прав і можливостей громадян, а також розширює урядові проекти та політику та робить їі більш орієнтованою на державні рішення громадян [28]. Отже, успіх у застосуванні електронного уряду великою мірою залежить від управління знаннями. «Управління знаннями для застосування електронного уряду більше не $\epsilon$ вибором, а стає імперативом в епоху приватизації, лібералізації та глобалізації» [19]. Таким чином, електронний уряд - це не просто перехід від ручного керування до цифрового; це колективне бачення всієї діяльності, бачення та місії врядування.

Оскільки електронне врядування значною мірою вимагає знань, для уряду потрібні програми та методи управління знаннями. Це викликає низку проблем, iз якими зіштовхуються держави у запровадженні електронного уряду:

- Контент електронного уряду має випадковий характер: часто він не організований осмислено для полегшення доступу до інформації.

- Інформація не оновлюється регулярно, що перешкоджає прийняттю обгрунтованих рішень у всіх секторах державного та недержавного секторів. Наприклад, в індустрії туризму інформація має велике значення як для державного, так і для 
приватного секторів для вироблення обгрунтованої політики. Застаріла інформація та мертві посилання засмучують користувачів, іноді вони можуть не усвідомлювати, що відповідна інформація є надмірною.

- Відсутня вся необхідна інформація, тому електронний портал залишається неповним.

- Більшість сайтів електронного уряду не допускають взаємодії громадян та уряду. Це перешкоджає розширенню прав і можливостей громадян і прозорості уряду, тоді як управління знаннями - це динамічний та інтерактивний інструмент стратегічного управління.

- Використання застарілих інформаційних технологій: найчастіше новітні інформаційні технології не використовуються або не впроваджуються досить швидко, щоб йти у ногу зі світовою спільнотою, і це негативно впливає на ініціативи електронного уряду.

- Урядові портали часто розробляються «непрофесіоналами», котрі не навчені інструментам і методам застосування знань. Вони не знають, як правильно створювати, фіксувати, зберігати, ділитися й оновлювати інформацію на порталах.

- Знання представлені у стандартному форматі, який може не підходити для всіх громадян і зацікавлених сторін. Щоб вирішити цю проблему, деякі електронні уряди почали надавати багатоканальні послуги офлайн й онлайн. Наприклад, електронний уряд Сінгапуру надає окремі послуги електронного громадянина різним групам користувачів і спеціальні послуги лише для дітей.

- Значення інтелектуального аналізу даних та управління знаннями: інтелектуальний аналіз даних - ще один інструмент для отримання інформації та допомоги у прийнятті обгрунтованих рішень. В електронному уряді основна увага в інтелектуальному аналізі даних приділяється управлінню взаємодіями між урядом і громадянами чи бізнесом, тоді як за допомогою інтелектуального аналізу даних можна отримати значний обсяг знань із кількох державних транзакційних даних i розширити можливості прийняття рішень.

- Помилковий підхід до електронного уряду: поточна практика електронного уряду у країнах, що розвиваються, залежить від конкретного проекту. Такий підхід заважає ініціативам електронного уряду. Оскільки створення електронного уряду спрямоване на покращення публічних послуг, його не слід розглядати як проект, який можна зробити, вичистити та забути. Його слід розглядати як постійний підхід у масштабі всього уряду, за якого знання необхідно аналізувати й оновлювати, щоб надавати найсвіжішу інформацію громадянам та іншим заінтересованим сторонам.

- Відсутнє сильне керівництво для розуміння, мотивації, залучення, впливу та підтримки ініціатив електронного уряду.

- Бюджетні обмеження перешкоджають доступності базової інфраструктури для широкого застосування електронного уряду.

- Відсутня хороша політика та законодавство для вироблення дорожньої карти та плану дій з управління знаннями на державних електронних порталах.

- Відсутність недооцінки етичної поведінки в електронному уряді - ще одна проблема, що викликає занепокоєння [19; 20].

Розвиваючи управління знаннями на рівні публічного сектору з використанням елементів електронного уряду, слід пам'ятати про низку застережень. Сучасна управлінська парадигма, яка грунтується на активному використанні у системі публічного управління також елементів суспільних мереж, не повною мірою покладається на інструменти електронного уряду. Залучення громадянського 
суспільства до розробки й удосконалення державної політики є гарним прикладом переходу від мислення «держава для вас» до мислення «держава 3 вами» для стимулювання знань про спільну творчість [26].

Для цього потрібно вирішити три завдання:

1. Створити культуру обміну всередині та за межами публічного управління.

2. Полегшити донесення своїх пропозицій громадянами до влади через загальнодоступні веб-ресурси та портали.

3. Застосувати інтелектуальні інструменти/системи для перетворення інформації на знання (контекстуалізація), а потім їх трансформації (застосування).

На жаль, сьогодні в Україні уряд не володіє достатніми ресурсами, внутрішніми навичками й інтелектом для ефективного задоволення потреб громадян у середовищі, що швидко змінюється. Світовий досвід доводить, що ефективність публічного управління забезпечується не тільки урядом, а й співробітництвом його з іншими суб'єктами суспільних відносин. Поділ влади, відкриття процесу ухвалення рішень, налагодження нових відносин і партнерство у сфері надання послуг - це основи уряду XXI ст. [15].

Висновки. Незважаючи на те, що управління знаннями широко обговорювалася багатьма теоретиками та практиками, література та/або інформація про управління знаннями на рівні публічного сектору $є$ недостатньою. Хоча відомо, що зміни в управлінні важче здійснити на рівні публічного сектору, а тиск із боку конкурентів і стимули для зниження витрат традиційно були менш важливими порівняно із приватним сектором, відсутність досліджень 3 управління знаннями у публічному секторі є серйозною проблемою. Парадокс складається у тому, що активне застосування управління знаннями може зробити свій внесок у реформу публічного управління, щоб зробити публічну владу більш ефективною, прозорою, чуйною до потреб громадян та ефективною у досягненні своїх цілей.

Для підвищення ефективності надання публічних послуг державні органи влади мають вийти за рамки електронного уряду (відкритість, доступність, ефективність і результативність), створюючи коло інновацій та адаптації політики за допомогою інтеграції знань і досвіду великої кількості зацікавлених сторін, котрі мають незрівнянно більшу здатність створювати знання.

\section{СПИСОК ВИКОРИСТАНОЇ ЛІТЕРАТУРИ:}

1. Бенсік А., Богнар К. Критерії успіху організації. Яка базується на знаннях або необхідність зміни стилю управління. Проблеми та перспективи управління в економіці. 2007. № 2. С. 50-60.

1. Дущенко О.С. Огляд історії розвитку Web. Фізико-математична освіта. 2018. № 2 (16). С. 46-50.

2. Костыгин Д. Управляешь знаниями - управляешь миром. Экономист. 2005. № 4. C. 4-5.

3. Нордстрем К. Бизнес в стиле фанк навсегда. Капитализм в удовольствие. Москва, 2010. $328 \mathrm{c}$.

4. Andersen A. \& APQC. The KM Assessment Tools: External Benchmarking Version, Winter. 1996.

5. Boston, J., Martin, J., Pallot, J. \& Walsh, P. Public Management: The New Zealand Model. Auckland: Oxford University Press, 1996.

6. Brun, C. KM toolbox: inventory of tools and techniques, Knowledge Management Specialist Library, National Library of Health, National Health Service, UK. 2005.

7. Cong, X. \& Pandya, K.V. Issues of Knowledge Management in the Public Sector. Electronic Journal of Knowledge Management. 2003. № 1 (2), P. 25-32. 
8. Despres, C. \& Chauvel D. Knowledge management(s). Journal of Knowledge Management. 1999. № 3 (2). P. 110-120.

1. Despres, C. (Ed.) Leading Issues in Knowledge Management Research. Reading, UK: Academic Publishing international, 2011.

2. Donate, M.J. \& de Pablo, J.D.S. The role of knowledge-oriented leadership in knowledge management practices and innovation. Journal of Business Research. 2015. № 68 (2). P. 360-370.

3. Drucker, P. Post-capitalist society. Harper Business : New York, 1993.

4. Gurteen, D. Knowledge, Creativity and Innovation. Journal of Knowledge Management. 1998. № 2 (1). P. 5-13.

5. Heeks, R. Benchmarking E-Government: Improving the National and International Measurement Evaluation and Comparison of E-Government. Evaluation of Information Systems. Oxford, Butterworth-Heinemann. 2008.

6. Ho, P. Governance at the Leading Edge: Black Swans, Wild Cards and Wicked Problems. Ethos. 2008. № 4. P. 74-79.

7. Larbi, G.A. The New Public Management Approach and Crisis States UNRISD Discussion Paper, 112, September. 1999.

8. Ling, T. Delivering joined-up government in the UK: dimensions, issues and problems. Public Administration. 2002. № 80 (4). P. 615-642.

9. Mangelsdorf, M. Von Babyboomer bis Generation Z: Der richtige Umgang mit unterschiedlichen Generationen im Unternehmen: GABAL Verlag GmbH, 2015. 171 p.

10. Misra, D.C. Ten Guiding Principles for Knowledge Management in E-government in Developing Countries. Proceedings of First Intl. Conference on KM for Productivity and Competitiveness, New Delhi. 2007.

11. Misra, D.C. Select Aspects of Conceptual Foundations of E-government, New Delhi, GIFT Publishing, 2008. P. 21-33.

12. Nonaka, I. \& Takeuchi, H. The Knowledge-Creating Company. New York : Oxford University Press, 1995.

13. OECD. Conclusions from the Results of the Survey of Knowledge Management Practices for Ministries/Departments/Agencies of Central Government in OECD Member Countries, February 3-4. 2003.

14. Rosenbloom, D.H. Understanding Management, Politics and Law in the Public Sector. New York : McGraw-Hill, 1998.

15. Skyrme, D.J. Knowledge Networking: Creating the Collaborative Enterprise. Oxford, 1999.

16. Sutton, M.J.D. Accepting knowledge management into the LIS fold: an interdisciplinary approach. Library Student Journal. 2007. № 2 (1). P. 1-9.

17. Tapscott, D., Williams, A.D. \& Herman, D. Government 2.0: Transforming Government and Governance for the Twenty-First Century. New Paradigm. 2008. January. P. 1-25.

18. Wart, M.V., Hondeghem, A., Bouckaert G. \& Ruebens S. Administrative Leadership in the Context of Governance. Paper for the XVI Annual Conference of the International Research Society for Public Management Panel on Leadership in the public sector: back to the future?. Rome, Italy, 2012.

19. Zhou, Z., Gao, F. E-government and Knowledge Management. International Journal of Computer Science and Network Security. 2007. № 7 (6). P. 285-289.

\section{REFERENCES:}

1. Bensik, A. \& Bohnar, K. (2007). Kryterii uspikhu orhanizatsii. Yaka bazuietsia na znanniakh abo neobkhidnist zminy styliu upravlinnia. [Criteria for the success of the organization. Based on knowledge or the need to change management style] Problemy ta perspektyvy upravlinnia v ekonomitsi, 2, 50-60 [in Ukrainian]. 
2. Dushchenko, O. (2018). Ohliad istorii rozvytku Web [Overview of the history of Web development] Fizyko-matematychna osvita: naukovyi zhurnal. 2 (16), 46-50. [in Ukrainian].

3. Kostygin, D. (2005). Upravlyayesh' znaniyami - upravlyayesh' mirom [You manage knowledge - you control the world]. Ekonomist, 4, 4-5 [in Russian].

4. Nordstrem, K. (2010). Biznes v stile fank navsegda. Kapitalizm v udovol'stviye [Funky business forever. Capitalism is fun]. Moskva, 328 p. [in Russian].

5. Arthur Andersen and APQC (1996). The KM Assessment Tools: External Benchmarking Version, Winter.

6. Boston J., Martin, J., Pallot, J. \& Walsh, P. (1996). Public Management: The New Zealand Model. Auckland: Oxford University Press

7. Brun Caroline (2005). KM toolbox: inventory of tools and techniques, Knowledge Management Specialist Library, National Library of Health, National Health Service, UK.

8. Cong X., and Pandya K.V. (2003). Issues of Knowledge Management in the Public Sector, Electronic Journal of Knowledge Management. Vol 1. Issue 2, pp. 25-32.

9. Despres C. \& Chauvel D. (1999). Knowledge management(s), Journal of Knowledge Management, № 3 (2), pp. 110-120.

10. Despres C. (Ed.) (2011). Leading Issues in Knowledge Management Research. Reading, UK: Academic Publishing international.

11. Donate M.J. and de Pablo J.D.S. (2015). The role of knowledge-oriented leadership in knowledge management practices and innovation. Journal of Business Research, № 68 (2), pp. 360-370.

12. Drucker P. (1993) Post-capitalist society. Harper Business: New York

13. Gurteen D. (1998). Knowledge, Creativity and Innovation. Journal of Knowledge Management, Vol 2, № 1, pp. 5-13.

14. Heeks R. (2008). What is E-Government? Accessed 14 March 2009: http://www.egov4dev.org/success/definitions.shtml.

15. Ho P. (2008). Governance at the Leading Edge: Black Swans, Wild Cards and Wicked Problems. Ethos. № 4, pp. 74-79.

16. Larbi G. A. (1999). The New Public Management Approach and Crisis States UNRISD Discussion Paper, № 112, September.

17. Ling T. (2002). Delivering joined-up government in the UK: dimensions, issues and problems, Public Administration, Vol 80, № 4, pp. 615-642.

18. Mangelsdorf M. (2015). Von Babyboomer bis Generation Z: Der richtige Umgang mit unterschiedlichen Generationen im Unternehmen: GABAL Verlag GmbH, $171 \mathrm{p}$.

19. Misra D.C. (2007). Ten Guiding Principles for Knowledge Management in E-government in Developing Countries. In Proceedings of First Intl. Conference on KM for Productivity and Competitiveness, New Delhi.

20. Misra D.C. (2008). Select Aspects of Conceptual Foundations of E-government: Clearing the Fog for a Better Vision, in Agarwal, Ashok and V. Venkata Ramana (2007): Foundations of E-government, New Delhi, GIFT Publishing, pp. 21-33.

21. Nonaka I. \& Takeuchi H. (1995). The Knowledge-Creating Company. New York: Oxford University Press.

22. OECD (2003). Conclusions from the Results of the Survey of Knowledge Management Practices for Ministries/Departments/Agencies of Central Government in OECD Member Countries, February 3-4.

23. Rosenbloom, D.H. (1998). Understanding Management, Politics and Law in the Public Sector (New York: McGraw-Hill).

24. Skyrme D.J. (1999). Knowledge Networking: Creating the Collaborative Enterprise. Oxford. 
25. Sutton M.J.D. (2007). Accepting knowledge management into the LIS fold: an interdisciplinary approach, Library Student Journal, № 2 (1), pp. 1-9.

26. Tapscott, D., Williams, A.D. \& Herman, D. (2008). Government 2.0: Transforming Government and Governance for the Twenty-First Century. New Paradigm, January 2008, pp. 1-25.

27. Wart M.V., Hondeghem A., Bouckaert G., Ruebens S. (2012). Administrative Leadership in the Context of Governance. Paper for the XVI Annual Conference of the International Research Society for Public Management Panel on Leadership in the public sector: back to the future?. Rome, Italy

28. Zhou Z., Gao F. (2007). E-government and Knowledge Management. IJCSNS International Journal of Computer Science and Network Security, № 7(6), pp. 285-289. 